\title{
Possibilities for Inter-Destination Collaboration in Tourism in the Case of Opatija and Portorož: A Managerial Perspective
}

\author{
Ksenija VODEB, Helena NEMEC RUDEŽ \\ Faculty of Tourism Studies - Turistica, University of Primorska, Portorož, \\ Slovenia \\ ksenija.vodeb@fts.upr.si,helena.nemec@fts.upr.si
}

\begin{abstract}
Intense competition among tourist destinations raises interest in inter-destination collaboration as a tool for developing innovative inter-destination products. The study presented in this paper examined the motives, barriers and expected outcomes of inter-destination collaboration in two Mediterranean tourist destinations - Opatija and Portorož - that are recognised as good mutual substitutes for tourists. Twenty management-level representatives of tourism or tourism-related organisations in Opatija and Portorož were interviewed to evaluate how they perceived inter-destination collaboration. The study revealed that inter-destination collaboration is recognised as an important tool for bridging the tourism destination products that are designed internally in order to develop inter-destination products. The study also revealed the motives for inter-destination collaboration based on the destinations' complementarity, collaboration barriers based on the destinations' similarities as well as differences and outcomes that are expected from inter-destination collaboration that bridges the tourism products developed separately in each destination. Participants expressed positive attitudes towards an innovative tourist offer and arrangements for the new and distant markets aiming to overcome the seasonality and upgrade the quality of destination products. Furthermore, the findings indicated that inter-destination collaboration might be successfully employed between destinations with poor intra-destination collaboration that are close substitutes. Practical implications of the results are discussed and further research is considered.
\end{abstract}

Key words: tourism; collaborative advantage in tourism, inter-destination collaboration; Mediterranean tourist destinations 


\section{Introduction}

Although several tourism destination competitiveness models have been developed so far, the intense competition among destinations raises further interest in this issue, posing new challenges at the level of inter-destination collaboration. Tourism destinations with good substitutive destinations can hardly gain a unique market positioning. Mediterranean destinations, largely relying on the $3 \mathrm{~S}$ tourism (sun, sea and sand) are viewed as good substitutes by tour operators and tourists. Consequently, the pressure on prices and profit margins are becoming increasingly high in these destinations, although many destinations have included the elements of cultural and/ or natural heritage in their tourism supply. In addition, the Mediterranean destinations are facing intense competition from the new long-haul seaside destinations. Since the late 20th century, many destinations have thus been attempting to develop competitive tourism products through collaboration and partnership in order to meet new challenges and to widen their market opportunities.

The traditional orientation of destination competition is being gradually replaced by a collaborative orientation of destinations (Fyall, Garrod and Tosun, 2006), which is considered a sine qua non in the highly competitive tourism market. So far, the research in the field of tourism destination has focussed mainly on intra-destination collaboration, while the literature on destination inter-collaboration has emerged only recently (for instance, Wang and Fesenmaier, 2007; D'Angella and Go, 2009; Fyall, Garrod and Wang 2012; Ness et al., 2014; Jegdić et al., 2015). The aim of the present paper is to enhance the understanding of the potentials of inter-destination collaboration by examining the motivations, barriers and expected outcomes of inter-destination collaboration, particularly in the case of geographically close destinations that are recognised as good substitutes. The study findings are expected to contribute to the understanding of the means to bridge the separately developed tourism destination products through inter-destination collaboration in order to develop a competitive inter-destination product.

\subsection{Tourism destination collaboration}

Destination competition has intensified with the development of government-owned and private destination organisations and administrators, higher destination marketing budgets, increased awareness and implementation of destination market research and destination competitiveness strategies 
(Crouch and Ritchie, 2006: 420-421). Destinations should be attractive to visitors, investors and residents as argued by Kotler, Haider and Rein (1993: 2), who introduced the LIV principle, underlining that a tourism destination should be liveable, investible and visitable.

Destination competitiveness is a complex concept that has been elaborated by several models. Crouch (2007: 2) identified three groups of destination competitiveness studies: studies analysing the competitive positions of specific destinations, studies focussing on the particular aspects of destination competitiveness (e.g. destination management systems, price competitiveness and the environment) and studies focussing on the general models of destination competitiveness. More recently, Fyall, Garrod and Wang (2012) highlighted the importance of collaborative advantage among destinations over competitive advantage. Similarly, Woodside and Dubelaar (2002) stated that collaboration could substitute competitiveness among tourism suppliers in order to create a wholesome tourism experience. Moreover, Wang (2008) argued that destination collaboration is a natural reaction to the management challenges of contemporary destinations.

Mariani et al. (2014: 270) noted that one of the key issues and current trends in destination management and marketing is an increasing importance of collaboration, not only within a destination, but also between destinations. They explained that by pointing to the fact that competition among tourism destinations is constantly on the rise, resulting in the competitive advantage becoming increasingly short-term. That makes collaboration with tourism destinations a relevant strategy for a destination to obtain competitive advantage in the long run. Collaborative attitudes and partnership among destinations can result in numerous positive effects and advantages for all of the stakeholders involved.

The microeconomic theory depicts collaboration as a tool for maintaining or improving the productive efficiency of an organisation (Ross, 1973, in Fyall, Garrod and Wang, 2012). D'Angella and Go (2009: 430) defined collaboration as a "formal institutionalised relationship among existing networks of institutions, interests and/or individual stakeholders". In fact, collaboration has the power to enhance destination competitiveness and contribute to the development of a destination (Fyall, Garrod and Wang, 2012) by highlighting its collaborative advantage. Ness et al. (2014) found that cooperation and coordination among destinations represent the prerequisites for destination innovation and renewal. Thus, the collective destination ef- 
forts for the creation of a new value for tourism products influence destination development. Haugland et al. (2011) argued that inter-destination bridge ties as important information channels can inspire innovation by delivering new information and ideas.

As a fragmented industry (Scott, 2013; D’Angella and Go, 2009; Wang, 2008), tourism calls for collaboration among destination tourism suppliers inside and across the destinations. The unstable environment forces suppliers to collaborate in order to gain competitive advantage (Czernek, 2013). One of such advantages is the development of cooperation between destinations and their connection into wider tourist regions (Jegdić et al., 2015). Indeed, a destination consists of many stakeholders with different expectations and perceptions of the final destination product. Fyall, Garrod and Tosun (2006) argued that inter-destination collaboration aims to form some kind of network that requires trust and commitment between partners. Haugland et al. (2011) described destinations as complex co-producing networks that need to act in a coherent manner. Tourism suppliers have different visions and values requiring negotiation and constructive dialogue. A collaborative destination strategy relies on coordination, communication, and consensus building (Wang, 2008). Additionally, according to Haugland et al. (2011), inter-destination collaboration should be inclusionary and, being a collective activity, requires collective learning and consensus building.

Considering that collaboration is a shared decision-making process (Gray, 1985 in Wang and Fesenmaier, 2007; D’Angella and Go, 2009), destination management should share knowledge and information as part of inter-destination collaboration. Żemła (2014) stated that tourism destinations are networks which need to participate in network cooperation to recompense for their fragmented nature. Therefore, networking inevitably requires an orchestrated coordination among the participants and represents a prerequisite for any collective action.

\subsection{Motives, enhancing factors, inhibiting factors and expected outcomes of inter-destination collaboration}

Motives and obstacles for the collaboration among tourism destinations have been addressed recently in many academic papers (for instance, Jegdić et al., 2015; Żemła, 2014; Czernek, 2013; Wang et al., 2013; Fyall, Garrod and Wang, 2012; D’Angella and Go 2009; Wang, 2008; Wang and Fesenmaier, 2007). Wang (2008) argued that a destination collaborative strat- 
egy can create harmony and synergy, new opportunities and can improve productiveness. Further, Wang and Fesenmaier (2007: 286) listed three main categories of destination collaborative motivations: transaction-cost oriented, strategy-oriented and learning-oriented. Transaction-cost oriented motivations refer to the achievement of lower costs and higher efficiency, strategy-oriented motivations are related to increasing the competitive position through tourism resource valorisation, while social- and learning-oriented motivations bring immense opportunities for building a unique and powerful competitive advantage through know-how, expertise and skills exchange (innovation through learning). Moreover, among the reasons for inter-destination collaboration, Żemła (2014) highlighted the development of new visitor attractions generated from shared tourism resources. Wang et al. (2013) listed technical changes in the environment, risk reduction and market opportunities through joint branding, image building and integrated tourism products. Weidenfeld (2013: 195) described the "integrated innovation space" within cross-border regions, where mutually beneficial and synergistic relations may lead to tourism innovation. Knowledge creation and exchange is vital for the destinations seeking to gain and maintain the competitive advantage. However, tourism innovations usually involve minor changes or improvements such as quality innovations, resulting in differentiations, product line extension, new destinations, development of new marketing segments, new organisational forms, etc.

Motivations for collaboration can emerge among destinations with similar tourism resources and products as well as among destinations with different but compatible tourism offers (Żemła, 2014). In the first case, inter-destination collaboration might be developed inside a geographically homogenous wider region, which is perceived as a single destination in the eyes of tourists, while in the second case, the collaboration issue could be based on compatibility and synergistic effects due to a diversity of sources, goods and attributes of destinations. According to Jegdić et al. (2015), the perception of potential benefits is the key point of collaboration, but Czernek (2013) warned that there are some country-specific cooperation determinants, especially in the post-transformation countries. They might include underdeveloped civil society, lack of experience in collaboration and financial difficulties facing local governments.

Regarding the circumstances favouring inter-destination collaboration, Wang et al. (2013: 285) noted that "tourist behaviours, the complementary 
nature of tourism products and geographic proximity call for a collaborative approach". Naipaul, Wang and Okumus (2009) stated that the assemblage of destinations is more likely to happen when destinations lie close to each other and/or offer compatible tourism products. Haugland et al. (2011: 278) argued that it is important for a destination "to be connected to the wider region and other destinations, as such connections can be valuable sources for the exchange of information and knowledge". Having in mind that tourists aim to maximise their travel experience (Naipaul, Wang and Okumus, 2009) by bundling different destinations throughout the region (rather than limit themselves to one part of region/destination), a joint regional marketing approach has a potential to intensify the attractiveness of a region by offering the same benefits (within the same market segments) or by providing complementary tourism products enlarging the consumption value for tourists.

According to Fyall, Garrod and Tosun (2006), the complexity of destination collaboration relationships emerges from a large number of stakeholders within the destination, making inter-destination collaboration more complex than intra-destination collaboration. D'Angella and Go (2009) considered the complexity of network relationships to be a barrier for the destination collaboration context and collaboration interaction. Consequently, in regard to inter-destination collaboration, Fyall, Garrod and Wang (2012) emphasised the need for reciprocity when striving toward a shared interest, trust and commitment between the collaborating partners, but also the fear of the unknown, distrust among the participants, imbalances of power, asymmetries and distances (physical and cultural) between the destinations. Indeed, there are notable inhibiting factors relating to inter-destination collaboration. Politics-related and governance factors, power imbalances, lack of trust and/or adequate resources (financial and/or human) are some of them. Haugland et al. (2011) forewarn about the lack of financial and managerial resources, limited time and disagreements among the stakeholders on cost sharing and benefits. Żemła (2014) also noted the culture and language, political will, local community support and accessibility (transport connections) as relevant barriers in inter-destination collaboration. Wang and Fesenmaier (2007) agreed that a positive local community attitude and a supportive atmosphere among the authorities are important for a successful partnership in this regard. Wang (2008) drew attention to collaborative arrangements in tourism, collaborative relationships and collective action undertaking by stakeholders. 
Buhalis (2000) stated that the most successful and competitive destinations cooperate with competing and complementary destinations. D'Angella and Go (2009: 429) went further still and highlighted that "destinations are involved in a race that demands understanding of the art of finding the right balance between sharing and hoarding resources and knowledge". It leads to the development of an integral tourism experience based on the fragmented elements of supply, regardless of the administrative borderline.

Competitive advantage could be gained by lower costs and differentiation (Porter, 1990). Applying these two basic generic types of competitive strategies to destinations, Buhalis (2000: 108) argued that destinations should avoid pursuing cost competitive advantage strategies because they are "based on mass production and consumption and assume unlimited production capacity and resources". However, the expected outcomes of interdestination collaboration are a decrease in destination costs and increased cost competitive advantage resulting from shared destination costs without increasing the production volume and mass production of tourism products. Moreover, inter-destination competitive advantage is oriented towards the achievement of a sustainable balance between the economic, socio-cultural and environmental impacts (Ritchie and Crouch, 2011).

\subsection{Research objective}

An inter-destination collaboration strategy requires an in-depth understanding of possible collaboration activities, forms of collaboration and collaboration barriers. The objective of the study was to understand how destinations which are recognised as close substitutes and do not have a high level of intra-destination collaboration, can collaborate to improve their competitive positions. More specifically, the study attempted to (a) evaluate the motives for cooperation between the destinations, (b) identify the inhibiting factors for inter-destination cooperation and (c) identify the expected outcomes of collaboration between the two destinations. The study focussed on Opatija and Portorož, two destinations that are perceived from the demand-side as perfect substitutes and strong competitors during the summer season (Prašnikar, Brenčič-Makovec and Knežević-Cvelbar, 2006).

\section{The choice of the study sites}

The collaboration between the two seaside Mediterranean destinations of Portorož and Opatija was undertaken as the two are major tourism 
destinations in the North-Eastern Adriatic region and among the most visited seaside destinations in that region. In 2015, there were 1,408,780 tourists overnight stays in Portorož and 1,219,538 in Opatija (Statistical Office of the Republic of Slovenia, 2016; Croatian Bureau of Statistics, 2016). Matznetter (1979, in Weidenfeld, 2013: 199) noted that "the location of cross-border tourism region can be classified by the three-fold typology according to their proximity to the borderline: distant from tourist areas, adjacent to the borderline on one side only, and areas that extend across, or meet at the borders". However, inter-destination collaboration can also include remote destinations where the connection is based on mutual resources (Jegdić et al., 2015: 35). Opatija and Portorož are not immediate-neighbour destinations, but that does not necessarily prevent them from efficient inter-destination collaboration. They are the remains of the so-called Austrian Riviera, share a common tourism development history and were interdependent through their past. Besides, research on Opatija and Portorož provides an insight into two very good substitutive destinations, giving an additional challenge to identifying inter-destination collaboration between the destinations that put their efforts into attracting the same market. Additionally, tourism industry representatives from the two destinations are assumed to know both destinations well and can provide their insights relevant for our analyses.

In many ways, Portorož and Opatija share various similarities, especially in terms of the cultural context since both belong to the "Mediterranean society" and have shared a long common history within the Austro-Hungarian Monarchy prior to World War I and within Yugoslavia following World War II. They are affluent with cultural and historical heritage, natural beauty and mild Mediterranean climate. In terms of population size, Opatija has 11,659 inhabitants while Portorož has 17,858 inhabitants (Croatian Bureau of Statistics, 2016; Statistical Office of the Republic of Slovenia, 2016). Both are located on the Istrian Peninsula in the north-eastern part of the Adriatic Sea, positioned $80 \mathrm{~km}$ from each other. Portorož is located on the north-western edge of the Istrian Peninsula and lies in Slovenia, while Opatija is situated in the Gulf of Kvarner on the north-eastern edge of the Istrian Peninsula, lying in Croatia. Both countries are part of the European Union, and the movement of people 
between them will be entirely unobstructed by border controls once Croatia joins the Schengen Area.

Portorož and Opatija share a similar tourism development history. Both were important luxury seaside tourism destinations in the "Austrian Riviera" of the Austro-Hungarian Empire until World War I. The Austrian Southern Railway Company was a major driving force behind the development of the Adriatic coast as a tourism destination for the wealthy Viennese clientele in the latter decades of the 19th century. Large-scale investments and big construction activities transformed Opatija into an international seaside resort with grand hotels, promenades, baths and various entertainment facilities (Vasko-Juhász, 2014). Mild Istrian winters were believed to be particularly beneficial for patients suffering from heart conditions and tuberculosis. By the late 1890s Opatija turned into a fashionable seaside resort, promoting its tourism industry through the summer season (Gottsmann, 2014). Besides these obvious attractions and benefits, Opatija was fascinating for young artists and intellectuals. In 1912 Egon Schiele, a well-known Austrian painter, impressed by the scenery, wrote: "In eight days here, you can do as much as in one year in Vienna!" (Oehring, 2014). At that time, the Adriatic was a new unique exotic place (concerning the light, sun, atmosphere, landscape, etc.) that inspired artists and intellectuals for journeys and accommodation. Such new discoveries and originality could be a catalyst for tourism development boosting its potentials in line with the visitor's expectations. Tourism development decreased in both destinations after World War I, as the two locations were assigned to Italy, which had many other seaside destinations. After World War II, they became part of Yugoslavia. In the 1970s and 1980s Opatija and Portorož were oriented toward summer leisure and MICE (meeting, incentives, congresses and events) tourism development, reaching their mature stage of life-cycle in the 1990s.

The similar history and development of the two destinations is responsible for similar segments of tourists as found by Prašnikar, BrenčičMakovec and Knežević-Cvelbar (2006). Moreover, both destinations are characterised by high seasonality and summer peak season. Each destination accounts for approximately $40 \%$ of yearly overnight stays during the high season (July and August) (Statistical Office of the Republic of Slovenia, 2016; Croatian Bureau of Statistics, 2016). Thus, destinations under 
the study are very similar and very close substitutes (Prašnikar, BrenčičMakovec and Knežević-Cvelbar, 2006), making inter-destination collaboration even more demanding. Tourists in Opatija and Portorož have comparable preferences and select similar tourism products for which they are willing to pay more. There is no significant difference between Opatija and Portorož in the current consumption level among tourists. They are mainly middle-aged individuals, travelling with families or partners, and usually represent a higher-income class (Prašnikar, Brenčič-Makovec and Knežević-Cvelbar, 2006).

Finally, Opatija and Portorož are both struggling with poor intra-destination collaboration among the suppliers within the destination (Prašnikar, Brenčič-Makovec and Knežević-Cvelbar, 2006: 249, 251). That was confirmed more recently by Sedmak, Planinc and Planinc (2011), who found that intra-destination collaboration was poor in Slovenia in general (Sedmak, Planinc and Planinc, 2011), as well as by Uran Maravić, Gračan and Zadel (2015), who confirmed that the tourism industry of Opatija is even less competitive than the tourism industry of Portorož. Thus, supply-based inter-destination cooperation between these two substitute destinations should be challenging and raises a question of whether two similar and close destinations with poor intra-destination collaboration could develop a tight inter-destination collaboration.

\section{Method}

A qualitative research method was used in the study. As the aim was to describe and clarify interactions and relationships through the views of individuals taking part in the research process, it was assumed that interviewing the key stakeholders would provide valuable and in-depth information about the issues under examination (Miles and Huberman, 1994; Pegg, Patterson and Gariddo, 2012). Due to the limited research conducted so far - this is the first attempt to research the possibilities of inter-destination cooperation between Opatija and Portorož - and inter-destination collaboration complexity, we assumed that employing a semi-structured interview would be useful for collecting a large range of opinions on the topic of interest.

The interviews were structured around several focal questions designed to cover the main aspects of the research objectives. According to Turner (2010), the general interview guide approach is more struc- 
tured than an informal conversational interview, but still provides room for free expression and for gathering rich and detailed information. Maxwell (2008) suggested an interactive model of research designed according to nonlinear components (i.e. goals, conceptual framework, research questions, methods, validity) interacting harmoniously through the research process. These guidelines were followed during the research design.

Semi-structured face-to-face interviews with representatives of tourism or tourism-related organisations were undertaken between April and June 2014 in Opatija and between August and September 2015 in Portorož. The research on inter-destination collaboration between Portorož and Opatija was focussed on the views of management-level representatives' from both locations. The selection of participants in Opatija was conducted with the assistance of the Head of the Department of Hospitality and Gastronomy at the Faculty of Tourism and Hospitality Management in Opatija, owing to his knowledge of the nature and scope of the local tourism industry. The same selection procedure was applied in Portorož with the assistance of the Head of the Department of Hospitality at the Faculty of Tourism Studies in Portorož.

Four different sectors of Opatija and Portorož tourism industries were included in the study: a) accommodation suppliers, b) tour operators, c) cultural, arts and event organisations and d) health tourism suppliers. A total of 37 tourism industry stakeholders from Opatija were contacted via e-mail and asked for an interview. Interview questions and a kind request to schedule the time of the interview were included. 10 of them agreed to participate in the study. In Portorož, a total of 27 representatives of the tourism industry were approached and 10 of them participated in the study. The number of participants within both destinations was relatively low, but the problem of data saturation may not be a significant issue due to a relative homogeneity of participants regarding their relevant characteristics (age, education, professional positions, etc.). Guest, Bunce and Johnson (2006: 59-60) found that saturation may occur "within the first twelve interviews, although basic elements for metathemes were present as early as six interviews". Thus, we assumed that 10 interviews in each destination, along with careful interviewee selection, were reasonably sufficient to reach useful study findings. Interviewees' characteristics for both destinations are presented in Table 1. 
Table 1: Sample characteristics by organisation, location, position, age and gender

\begin{tabular}{|c|c|c|c|c|}
\hline Type of organisation & Location & Position & Age group & Gender \\
\hline Hotel supplier & Portorož & Top manager & $30-40$ & Male \\
\hline Hotel supplier & Portorož & Top manager & $40-50$ & Male \\
\hline $\begin{array}{l}\text { Cultural, arts and event } \\
\text { organisation }\end{array}$ & Portorož & Manager & $40-50$ & Male \\
\hline $\begin{array}{l}\text { Cultural, arts and event } \\
\text { organisation }\end{array}$ & Portorož & Manager & $40-50$ & Male \\
\hline Hotel supplier & Portorož & $\begin{array}{l}\text { Marketing } \\
\text { manager }\end{array}$ & $30-40$ & Female \\
\hline $\begin{array}{l}\text { Local destination } \\
\text { management organisation }\end{array}$ & Portorož & Executive & $40-50$ & Female \\
\hline Wellness centre & Portorož & Manager & $30-40$ & Female \\
\hline Hotel supplier & Portorož & $\begin{array}{l}\text { Marketing } \\
\text { manager }\end{array}$ & $30-40$ & Male \\
\hline Tour operator & Portorož & Manager & $40-50$ & Female \\
\hline $\begin{array}{l}\text { Cultural, arts and event } \\
\text { organisation }\end{array}$ & Portorož & Manager & $30-40$ & Male \\
\hline Hotel supplier & Opatija & Top manager & $40-50$ & Male \\
\hline Health centre & Opatija & Top manager & $40-50$ & Male \\
\hline $\begin{array}{l}\text { Cultural, arts and event } \\
\text { organisation }\end{array}$ & Opatija & Manager & $50-60$ & Female \\
\hline Hotel supplier & Opatija & Top manager & $40-50$ & Male \\
\hline $\begin{array}{l}\text { Local destination } \\
\text { management organisation }\end{array}$ & Opatija & Executive & $40-50$ & Female \\
\hline Tour operator & Opatija & Manager & $20-30$ & Female \\
\hline $\begin{array}{l}\text { Regional destination } \\
\text { management organisation }\end{array}$ & Opatija & Executive & $30-40$ & Female \\
\hline Hotel supplier & Opatija & $\begin{array}{l}\text { Marketing } \\
\text { manager }\end{array}$ & $30-40$ & Female \\
\hline Hotel supplier & Opatija & Manager & $40-50$ & Male \\
\hline $\begin{array}{l}\text { Cultural, arts and event } \\
\text { organisation }\end{array}$ & Opatija & Manager & $30-40$ & Female \\
\hline
\end{tabular}

An initial interview protocol was designed based on a critical review of previous research (Naipaul, Wang and Okumus, 2009; Wang and Fesenmaier, 2007; D'Angella and Go 2009; Wang, 2008), which helped identify and prepare the interview questions. The interviews were conducted by the authors at the interviewees' business premises. During the interviews, the researchers were taking notes. Besides verbal communication, the re- 
searches were paying attention to nonverbal communication. The interviews lasted between one and two hours.

After an interviewee was explained the purpose of the research, he or she was asked to evaluate the competitiveness of Opatija and Portorož. The questions were composed of topics related to collaborative orientation (e.g. "What do you think about inter-destination collaboration in general?"), collaboration activities (e.g. "Do you have any kind of experience in inter-destination collaboration?", "Have you ever participated in interdestination collaboration?"), their personal experiences (e.g. "Could you describe an example of such collaboration?", "Who were the collaborators and what was the common goal of the collaboration?"), possible forms of collaboration between Opatija and Portorož (e.g. "What possible forms of collaboration between Opatija and Portorož would be appropriate in your opinion?"), as well as motives and inhibiting factors for collaboration between the destinations (e.g. "What would be the strengths of/barriers to collaboration?"). In addition to these main questions, probing questions were asked by the researchers, when necessary, to get more depth and details. Follow-up questions were used to encourage expansion of ideas most relevant to the research question and were useful for directing the flow of the interviews.

The contents of the interviews were analysed using the approach recommended by Naipaul, Wang and Okumus (2009). Inductive and deductive analyses were employed jointly. The inductive approach provided a framework-free data analysis, while the deductive (theoretically driven) approach served to evaluate existing theories. The application of both modes of analysis helped authors explain the gathered data and deepen the understanding of inter-destination collaboration. Data analysis was carried out as an ongoing process of data reduction, data display and data verification. A coding scheme was derived from the literature review. Data analysis comprised of breaking down the interview notes into manageable (rational) parts in order to classify them under each code. All the data were sifted and charted. This was carried out in three stages by each of the authors and comparisons were made among the authors' findings. The codes emerging from each author were crosschecked, discussed, compared and - where necessary - re-categorised to mitigate the subjectivity. In that way, the authors attempted to strengthen the validity and reliability of the findings. 


\section{Research findings and discussion}

Our analyses identified several indicators of the opportunities for interdestination collaboration between Opatija and Portorož as close substitutes, as well as some barriers. The findings from the two locations were fairly consistent and, thus, shed light on the possibilities of inter-destination development.

Destination vicinity and accessibility of tourist generating markets, as well as tourism tradition and history, were identified by interviewees in Opatija as the most important competitive advantages of Opatija in relation to Portorož. The tradition of health tourism is still embodied in the architecture, infrastructure and even gastronomy. Interviewees reported that the main problem of Opatija tourism competitiveness lies in the absence of strategic destination development resulting in a blurred image. One of the interviewees stated: "Tourism in Opatija cannot rest on its laurels of the golden era of tourism". "Things happening by inertia", "no destination strategy" and "destination as a mixed store" were identified as the main difficulties facing Opatija .

Destination location, its vicinity and accessibility, microclimate (located between two saltpans), as well as wellness and congress facilities were indicated as the most significant competitive advantages of Portorož in relation to Opatija according to the respondents from Portorož. The main shortcomings of Portorož tourism competitiveness, as indicated by the respondents, are the same as in Opatija: blurred vision and uncoordinated stakeholders as a result of the absence of the strategic development. Ownership structure of the hotels in Portorož (privatisation, financial problems) was perceived as an additional hindrance to tourism development. This is in line with a previous finding of Prašnikar, Brenčić-Makovec and KneževićCvelbar (2006) about a low degree of destination management efficiency.

The interviewees from both destinations perceived that Portorož and Opatija have similar tourism supply, but they also identified some notable differences. Opatija was perceived as more competitive than Portorož concerning its historical and architecture sites and gastronomy, whereas Portorož - according to our respondents - has a competitive advantage in congress facilities and saltpans. The differences between the two destinations are perceived among the interviewees from both destinations as a factor of compatibility and opportunity for the development of joint destination products. This is consistent with the findings of Weidenfeld (2013), 
who noted that similarities in tourism resources between neighbouring border regions are likely to enhance knowledge transfer at regional level and that product complementarities between businesses in neighbouring border regions are likely to enhance product innovations.

Motives and inhibiting factors for the collaboration between the two destinations, with the related expected outcomes, that emerged from the interviews are presented in Table 2.

Table 2: An outline of the main findings on the motives, barriers and expected outcomes of cooperation between Opatija and Portorož

\begin{tabular}{lll}
\hline Motives & Barriers & Expected outcomes \\
\hline Strategy-oriented motives: & Barriers arising from & Diversification: \\
- development of joint thematic & destinations similarities: & - supply \\
events and products (cultural, & - fear of additional & diversification \\
sports, health); & confusion among visitors & and quality \\
- design and promotion for & due to unclear destination & improvement. \\
organised group visitors from & image; & Economies of \\
distant and new markets; & - unsystematic & scope: \\
- design and promotion of & development & - knowledge and \\
tailor-made joint tourism & (development by inertia); & experience sharing; \\
arrangements. & insufficient local & - tourism product \\
Cost-oriented motives: & community integration. & innovation (joint \\
- joint destination promotion & Barriers based on the & stories)*; \\
(joint attendance at fairs and & differences between & - decrease of \\
exhibitions, joint marketing & destinations: & seasonality. \\
campaigns, joint promotional & - lack of and differences & Economies of \\
material, etc.), & between destinations in & scale: \\
- development of joint & knowledge, competences & - cost sharing; \\
distribution channels (joint & and experiences; & - larger market \\
reservation systems). & - differing quality of & share. \\
Learning-oriented motives*: & products and different & \\
- knowledge and experience & tourism management & \\
transfer. & mindset. & \\
\hline
\end{tabular}

* Perceived by respondents in Portorož only.

The area of motives and opportunities for inter-destination collaboration identified by our interviewees concerned primarily cultural, health and sports tourism, especially tailor-made tourist arrangements for group visitors, mainly from distant markets (e.g. Scandinavia and beyond Europe). Interviewees from Portorož recognised the possibilities for inter-destination collaboration by joining together compatible tourism resources and offers of each destination to develop an inter-destination product directed par- 
ticularly towards new and distant markets and to extend the main summer season. This is consistent with Jegdić et al. (2015) who noted that a destination can collaborate with another destination in one market and compete with it in another. Moreover, respondents from Portorož believed that the tradition of tourism in Portorož and Opatija might be an integrating factor for a better recognisability of each destination through inter-destination collaboration. Our findings are consistent with the findings of Wang (2008: 163), who argued that "cooperative activities are more likely to happen between tourism businesses that are interdependent (share a common history) and whose products are complementary to each other". The majority of interviewees from both destinations assumed that inter-destination collaboration should take a form of joint destination promotion (joint attendance at fairs and exhibitions, joint marketing campaigns, joint promotion materials, etc.). Naipaul, Wang and Okumus (2009) reported similar findings regarding the joint marketing approach and providing complementary tourism products. A couple of interviewees emphasised the importance of joint reservation systems and tourism arrangements. One interviewee advised that "local community integration is an urgent matter for the purpose of authentic local culture promotion and collaboration within joint projects".

Regarding the seasonality issues, collaboration between Opatija and Portorož seems to be a welcome strategy. One tourism manager stated the following: "Opatija and Portorož can collaborate, especially at the beginning and at the end of the peak season, and thus increase hotel occupancy in both destinations". According to the interviewees from Portorož, tourism industry in Portorož should generally attempt to pursue year-round tourism in both destinations. Furthermore, the interviewees in Portorož considered inter-destination collaboration as a tool to create fresh and innovative tourism offers, which is in line with Ness et al. (2014) and Haugland et al. (2011), who highlighted destination innovation and destination product renewal as a prerequisite for destination collaboration.

Previous experience, personal acquaintances, confidence in partners and tourism product compatibility were identified as the preconditions for inter-destination collaboration by the interviewees in both destinations. The relevance of collaboration preconditions was highlighted by the interviewee who argued that "we want to collaborate with familiar and trustworthy people when searching for joint projects". This is in line with the findings of Altinay, Brookes and Aktas (2013), who identified trust as a crucial criterion 
for inter-destination collaboration because trust contributes to mutual understanding and strengthens the spirit of collaboration. Czernek (2013) also identified the lack of experience, lower level of trust and lack of familiarity as the hindering determinants of collaboration. In contrast to the findings of Wang and Fesenmaier (2007), the motives for inter-destination collaboration as perceived in Opatija were not related to knowledge sharing, but only to cost-sharing and product enhancement. In contrast, the interviewees in Portorož recognised the transfer of knowledge and experience as an outcome of collaboration in addition to cost sharing and product enhancement.

The visitors' confusion regarding the destinations, lack of knowledge and competences, inertia and absence of destination strategy and insufficient local community integration into the decision making process were identified by the Opatija interviewees as the inhibiting factors for collaboration. Surprisingly, concerns were expressed about destination similarity (undifferentiated product) and destination differences regarding "the quality and tourism management mindset". These could be recognised as inhibiting factors for the cooperation between selected destinations. Likewise, inhibiting factors were detected in insufficient resources (knowledge, experience, etc.) for inter-destination collaboration. In Portorož, the main barriers for collaboration were recognised in different operation policy (e.g. payment system, visa system) and predominantly in uncoordinated local developmental strategy of a tourism destination. The latter was also identified by the interviewees from Portorož as a precondition for inter-destination cooperation. Czernek (2013) also noted a lack of knowledge and experience to be the main hindrance to collaboration. The present study revealed that it is the absence of systematic destination development, and not the competitive nature of destinations, that creates an obstacle to inter-destination collaboration, as found by Wang and Fesenmaier (2007).

The outcomes of collaboration can improve destination competitiveness. The findings from both destinations show that the outcomes of interdestination collaboration could be reflected in the heterogeneity of the tourism offer (richness, diversity and colourfulness), cost sharing, know-how, experience sharing, and a larger market share (particularly in new distant markets). Interviewees from both destinations recognised inter-destination collaboration as a vehicle for boosting the competitiveness of both destinations. High seasonality could also be decreased through an innovative joint tourism supply including the "stories and heritage" of the destinations. "The 
art of right balance between hoarding and sharing resources" (D'Angella and Go, 2009: 429) would be - in the case of our destinations - creating compatible tourism products out of the peak season by designing attractive and innovative tourism products meant to enhance year-round tourism.

\section{Conclusions}

The study aimed to provide an insight into inter-destination collaboration possibilities for two close seaside destinations, Opatija and Portorož, which are recognised as good substitutes (Prašnikar, Brenčić-Makovec and Knežević-Cvelbar, 2006). Our study revealed that the tourism industry representatives from both destinations share the views on inter-destination collaboration, its motives, barriers and expected outcomes. An inter-destination tourism product can be developed based on the current destinations' tourism products by bridging the motives and expected outcomes between the destinations establishing inter-destination collaboration.

The findings of the present research bear theoretical relevance and provide empirical contributions to the study of inter-destination collaboration. Firstly, the motives for inter-destination collaboration, divided into strategyoriented, cost-oriented and learning-oriented motives, corroborated Wang and Fesenmaier's (2007) motive classification in close substitutive destinations. Secondly, the study underlined that barriers to inter-destination collaboration arise from the destinations' similarities and differences. Thus, an in-depth knowledge of other destinations' characteristics is critical in identifying whether barriers to a successful inter-destination collaboration can be surmounted in destinations that are perceived as good substitutes. Thirdly, the expected outcomes of inter-destination collaboration were divided into those related to diversification, economies of scale and economies of scope. Following Wang and Fesenmaier (2007), these outcomes are predominantly strategy-oriented and reflect less on the learning or social capital orientation. However, contrary to our expectations, the analysis of the expected outcomes showed that, thus far, sustainability issues are not getting a proper amount of consideration when it comes to inter-destination collaboration. Fourthly, the findings of this study may encourage a discussion about the previous belief that intra-destination cooperation is a precondition for interdestination cooperation (Żemła, 2014; Jegdić et al., 2015). The respondents in our study declared the cooperative attitude, particularly regarding tourism product compatibility, as a starting point for building new, innovative tour- 
ist offer and arrangements for new and distant markets aiming to overcome the seasonality issues and upgrade destination product quality. In a broader cultural and historical context, it might be essential to consider the destinations' unique image, as perceived by destination managers. This could consequently lead to new collaborative advantages for both destinations.

Regarding the managerial implications, the research showed that interdestination collaboration might be employed successfully between destinations with poor intra-destination collaboration that are perceived as close substitutes. In fact, destinations with a high degree of seasonality, such as Opatija and Portorož, could ensure year-round tourism through joint tourism products. In line with Buhalis (2000), our results confirmed that both destinations are aware of collaboration outcomes derived from the competitive and complementary nature of their destination product. Unfortunately, the expected outcomes of inter-destination collaboration related to sustainability issues were not identified in the study, revealing that this area is underestimated by tourism organisations. Further analysis of potential costs and benefits of inter-destination collaboration is required as well.

The study presented in this article is exploratory, non-conclusive and constricted by several notable limitations. Its aim was to provide an insight into the inter-destination collaboration possibilities of two destinations from the point of view of tourism suppliers. The findings might inform the first steps in the process of establishing inter-destination collaboration between the two destinations. However, it is necessary to extend the research to the entire destination network (tourism industry representatives, public sector, local community and tourists) to enable a much more profound and multidimensional understanding of inter-destination opportunities, including the country-specific determinants. In addition, the inner efficiency and the performance of destination management should be studied further as the cooperation among stakeholders within a destination represents a starting point in the search of inter-destination opportunities. Additionally, it is recommended to extend the research on inter-destination to other types of destinations in the region (for instance, urban, mountain, rural and emerging seaside destinations). Research on the collaboration among more distant destinations would be welcome as well. Even so, the conclusions and recommendations arising from the findings of this study shed a new light on inter-destination collaboration and provide a good starting point for further research. 


\section{REFERENCES}

Altinay, Levent, Brookes, Maureen and Aktas, Gurhan (2013). "Selecting franchise partners: Tourism franchisee approaches, processes and criteria", Tourism Management, 37 (1): 176-185. doi: 10.1016/j.tourman.2013.01.016

Buhalis, Dimitrios (2000). "Marketing the competitive destination of the future", Tourism Management, 21 (1): 97-116. doi: 10.1016/S0261-5177(99)00095-3

Croatian Bureau of Statistics (2016). Statistical report No. 1564: Tourism, 2015. Zagreb: Croatian Bureau of Statistics.

Crouch, Geoffrey I. (2007). Modelling Destination Competitiveness: A Survey and Analysis of the Impact of Competitiveness Attributes. Gold Coast: CRC for Sustainable Tourism.

Crouch, Geoffrey I. and Ritchie, J. R. Brent (2006). "Destination competitiveness", in: Larry Dwyer and Peter Forsyth (eds). International Handbook on the Economics of Tourism. Cheltenham: Edward Elgar Publishing, pp. 419-433.

Czernek, Katarzyna (2013). "Determinants of cooperation in a tourist region", Annals of Tourism Research, 40: 83-104. doi: 10.1016/j.annals.2012.09.003

D’Angella, Francesca and Go, Frank M. (2009). "Tale of two cities' collaborative tourism marketing: Towards a theory of destination stakeholder assessment", Tourism Management, 30 (3): 429-440. doi: 10.1016/j.tourman.2008.07.012

Fyall, Alan, Garrod, Brian and Tosun, Cevat (2006). "Destination Marketing: A Framework for Future Research", in: Metin Kozak and Luisa Andreu (eds). Progress in Tourism Marketing. Oxford: Elsevier, pp. 75-86.

Fyall, Alan, Garrod, Brian and Wang, Youcheng (2012). "Destination collaboration: A critical review of theoretical approaches to a multi-dimensional phenomenon", Journal of Destination Marketing \& Management 1 (1-2): 10-26. doi: 10.1016/j.jdmm.2012.10.002

Gottsman, Andrea (2014). "Vor und hinter den Kullisen - Tourismus und nationale Spannungen", in: Christian Rapp and Nadia Rapp-Wimberger (eds). Abbazia und Istrien in Österreichischen Riviera. Wien: Wien Museum Czernin Verlag Katalog, pp. 76-95.

Guest, Greg, Bunce, Arwen and Johnson, Laura (2006). "How Many Interviews Are Enough? An Experiment with Data Saturation and Variability", Field Methods, 18 (1): 59-82. doi: 10.1177/1525822X05279903

Haugland, Sven A., Ness, Håvard, Grønseth, Bjørn Ove O., and Aarstad, Jarle (2011). "Development of tourism destinations: An integrated multilevel perspective", Annals of Tourism Research, 38 (1): 268-290. doi: 10.1016/j.annals.2010.08.008

Jegdić, Vaso. V., Tomka, Dragica, Knežević, Mladen, Koščak, Marko, Milošević, Srdjan, Škrbić, Iva and Keča, Ksenija (2015). "Improving Tourist Offer Through Inter-Destination Cooperation in a Tourist Region", International Journal of Regional Development, 3 (1): 31-49. doi: 10.5296/ijrd.v3i1.8304

Kotler, Philip, Haider, Donald H. and Rein, Irving (1993). Marketing Places: Attracting Investment. Industry, and Tourism to Cities, States, and Nations. New York: The Free Press. 
Mariani, Marcello M., Buhalis, Dimitrios, Longhi, Christian and Vitouladiti, Ourania (2014). "Managing change in tourism destinations: Key issues and current trends", Journal of Destination Marketing \& Management, 2 (4): 269272. doi: 10.1016/j.jdmm.2013.11.003

Maxwell, Joseph A. (2008). "Designing a qualitative study", in: Leonard Bickman and Debra J. Rog (eds). The Sage Handbook of Applied Social Research Methods. Thousand Oaks: SAGE, pp. 214-253.

Miles, Matthew B. and Huberman, A. Michael (1994). Qualitative Data Analysis: An Expanded Sourcebook. Thousand Oaks: SAGE.

Naipaul, Sandra, Wang, Youcheng and Okumus, Fevzi (2009). "Regional destination marketing: A collaborative approach", Journal of Travel \& Tourism Marketing, 26 (5-6): 462-481. doi: 10.1080/10548400903162998

Ness, Håvard, Aarstad, Jarle, Haugland, Sven A. and Grønseth, Bjørn-Ove (2014). "Destination Development: The Role of Interdestination Bridge Ties", Journal of Travel Research, 53 (2): 183-195. doi: 10.1177/0047287513491332

Oehring, Erika (2014). "Voyages Pittoresques - Bilder Von der Österreichischen Riviera", in: Christian Rapp and Nadia Rapp-Wimberger (eds). Österreichischen Riviera: Wien entdeckt das Meer. Wien: Wien Museum Czernin Verlag Katalog, pp. 95-114.

Pegg, Shane, Patterson, Ian and Gariddo, Pablo Vila (2012). "The impact of seasonality on tourism and hospitality operations in the alpine region of New South Wales, Australia", International Journal of Hospitality Management, 31 (3): 659-666. doi: 10.1016/j.ijhm.2011.09.001

Porter, Michael E. (1990). The Competitive Advantage of Nations. New Yor: The Free Press.

Prašnikar, Janez, Brenčič-Makovec, Maja and Knežević-Cvelbar, Ljubica (2006). "Exploring the challenges of destination management: Comparison of the supply and demand characteristics in four destinations in North Adriatic and Gorica region", in: Janez Prašnikar (ed). Competitiveness, Social Responsibility and Economic Growth. New York: Nova Science Publishers, pp. 245-267.

Ritchie, J. R. Brent and Crouch, Geoffrey I. (2011). "A Model of Destination Competitiveness and Sustainability", in: Youcheng Wang and Abraham Pizam (eds). Destination Marketing and Management: Theories and Applications. London: CABI, pp. 326-339. doi: 10.1079/9781845937621.0326

Scott, Noel (2013). "Tourism is a fragmented industry and policy area: Myth or reality?" Conference Proceedings of the Myths of Tourism Conference. Zagreb: Faculty of Economics and Business.

Sedmak, Gorazd, Planinc, Tanja and Planinc, Saša (2011). "Unexploited potentials of networking in the hospitality business - Slovenia's case", Tourism and Hospitality Management, 17 (2): 187-200.

Statistical Office of Republic of Slovenia (2016). Tourist arrivals and overnight stays in 2015. Ljubljana: Statistical Office of Republic of Slovenia.

Turner, Daniel W. III (2010). "Qualitative Interview Design: A Practical Guide for Novice Investigators", The Qualitative Report, 15 (3): 754-760. 
Uran Maravić, Maja, Gračan, Danijela and Zadel, Zrinka (2015). “A Comparison of the Competitiveness of the Two Coastal Tourist Destinations", Naše more, 62 (4): 120-126. doi: 10.17818/NM/2015/4.12

Vasko-Juhász, Desirée (2014). "Komfort und Kapital - Die Südbahn und Ihre Abbaziahotels", in: Christian Rapp and Nadia Rapp-Wimberger (eds). Österreichischen Riviera: Wien entdeckt das Meer. Wien: Wien Museum Czernin Verlag Katalog, pp. 66-75.

Wang, Youcheng (2008). "Collaborative Destination Marketing: Understanding the Dynamic Process", Journal of Travel Research, 47 (2): 151-166. doi: $10.1177 / 0047287508321194$

Wang, Youcheng and Fesenmaier, Daniel R. (2007). "Collaborative destination marketing: A case study of Elkhart County, Indiana", Tourism Management, 28 (3): 863-875. doi: 10.1016/j.tourman.2006.02.007

Wang, Youcheng, Hutchinson, Joe Okumus, Fevzi and Naipaul, Sandra (2013). "Collaborative Marketing in a Regional Destination: Evidence from Central Florida", International Journal of Tourism Research, 15 (3): 285-297. doi: $10.1002 /$ jtr. 1871

Weidenfeld, Adi (2013). "Tourism and cross border regional innovation systems", Annals of Tourism Research, 42: 191-213. doi: 10.1016/j.annals.2013.01.003

Woodside, Arch G. and Dubelaar, Chris (2002). "A general theory of tourism organizations systems: A conceptual framework and an experimental exploration", Journal of Tourism Research, 41 (2): 120-132. doi: 10.1177/004728702237412

Żemła, Michał (2014). "Inter-destination cooperation: Forms, facilitators and inhibitors - The case of Poland", Journal of Destination Marketing \& Management, 3 (4): 241-252. doi: 10.1016/j.jdmm.2014.07.001

\section{Mogućnosti turističke međuodredišne suradnje na primjeru Opatije i Portoroža: menadžerska perspektiva}

Ksenija VODEB, Helena NEMEC RUDEŽ

Fakultet za turističke studije, Sveučilište Primorska, Portorož, Slovenija ksenija.vodeb@fts.upr.si,helena.nemec@fts.upr.si

Snažna konkurencija među turističkim odredištima potiče interes za međuodredišnu suradnju kao alat za razvoj inovativnih zajedničkih proizvoda različitih odredišta. U studiji predstavljenoj u ovome radu istraženi su motivi, prepreke i očekivani ishodi međuodredišne suradnje u dvama mediteranskim turističkim odredištima - Opatiji i Portorožu - koja su prepoznata kao međusobno zamjenjiva turistička odredišta. Intervjuirano je dvadeset predstavnika menadžerskog sektora zaposlenih u turističkim organizacijama ili organizacijama povezanima s turizmom u Opatiji i Portorožu, s ciljem ispitivanja njihove percepcije međuodredišne surad- 
nje. Istraživanje je pokazalo kako je međuodredišna suradnja prepoznata kao važan alat za povezivanje turističkih proizvoda razvijenih na razini pojedinačnog odredišta s ciljem razvoja zajedničkih proizvoda različitih odredišta. Osim toga, istraživanjem su osvijetljeni motivi za međuodredišnu suradnju na temelju komplementarnosti odredišta, prepreke za međuodredišnu suradnju na temelju njihovih sličnosti te razlike i očekivani ishodi međuodredišne suradnje kojom se povezuju proizvodi koji su razvijeni zasebno, na razini pojedinačnog odredišta. Sudionici su izrazili pozitivan stav o inovativnoj turističkoj ponudi i aranžmanima za nova i udaljena tržišta s ciljem nadilaženja sezonalnosti i poboljšanja kvalitete proizvoda odredišta. Osim toga, rezultati su pokazali kako se međuodredišna suradnja može uspješno primijeniti u međusobno zamjenjivim odredištima u kojima postoji slaba unutarodredišna suradnja. U radu se razmatraju i praktične implikacije rezultata te daljnja istraživanja.

Ključne riječi: turizam, prednosti suradnje u turizmu, međuodredišna suradnja, mediteranska turistička odredišta 